\title{
Platiniferous Tetra-Auricupride: A Case Study from the Bolshoy Khailyk Placer Deposit, Western Sayans, Russia
}

\author{
Andrei Y. Barkov ${ }^{1, *}$, Nobumichi Tamura ${ }^{2}{ }^{(0}$, Gennadiy I. Shvedov ${ }^{3}{ }^{(0)}$, Camelia V. Stan ${ }^{2}$, \\ Chi Ma ${ }^{4}$, Björn Winkler ${ }^{5}$ and Robert F. Martin ${ }^{6}$ \\ 1 Research Laboratory of Industrial and Ore Mineralogy, Cherepovets State University, \\ 5 Lunacharsky Avenue, 162600 Cherepovets, Russia \\ 2 Advanced Light Source, 1 Cyclotron Road, Lawrence Berkeley National Laboratory, \\ Berkeley, CA 94720-8229, USA; ntamura@lbl.gov (N.T.); cstan@lbl.gov (C.V.S.) \\ 3 Institute of Mining, Geology and Geotechnology, Siberian Federal University, 95 Avenue Prospekt im. gazety \\ "Krasnoyarskiy Rabochiy", 660025 Krasnoyarsk, Russia; g.shvedov@mail.ru \\ 4 Division of Geological and Planetary Sciences, California Institute of Technology, 1200 East California Blvd., \\ Caltech, 170-25 Pasadena, CA 91125, USA; chi@gps.caltech.edu \\ 5 Institut für Geowissenschaften, Universität Frankfurt, Altenhöferallee 1, DE-60438 Frankfurt am Main, \\ Germany; b.winkler@kristall.uni-frankfurt.de \\ 6 Department of Earth and Planetary Sciences, McGill University, 3450 University Street, \\ Montreal, QC H3A 0E8, Canada; robert.martin@mcgill.ca \\ * Correspondence: ore-minerals@mail.ru; Tel.: +7-8202-51-78-27
}

Received: 12 February 2019; Accepted: 1 March 2019; Published: 7 March 2019

\begin{abstract}
Tetra-auricupride, ideally $\mathrm{AuCu}$, represents the only species showing the coexistence of $\mathrm{Au}$ with an elevated level of $\mathrm{Pt}$, as in the case of a detrital grain studied structurally for the first time, from an ophiolite-associated placer at Bolshoy Khailyk, western Sayans, Russia. We infer that tetra-auricupride can incorporate as much as $\sim 30 \mathrm{~mol}$. \% of a "PtCu" component, apparently without significant modification of the unit cell. The unit-cell parameters of platiniferous tetra-auricupride are: $a$ 2.790(1) $\AA, c 3.641$ (4) $\AA$, with $c / a=1.305$, which are close to those reported for ordered $\mathrm{AuCu}(\mathrm{I})$ in the system $\mathrm{Au}-\mathrm{Cu}$, and close also to the cell parameters of tetraferroplatinum $(\mathrm{PtFe})$, which both appear to crystallize in the same space group, $P 4 / \mathrm{mmm}$. These intermetallic compounds and natural alloys are thus isostructural. The closeness of their structures presumably allows $\mathrm{Pt}$ to replace $\mathrm{Au}$ atoms so readily. The high extent of $\mathrm{Cu}+\mathrm{Au}$ enrichment is considered to be a reflection of geochemical evolution and buildup in levels of the incompatible $\mathrm{Cu}$ and $\mathrm{Au}$ with subordinate $\mathrm{Pt}$ in a remaining volume of melt at low levels of $f \mathrm{O}_{2}$ and $f \mathrm{~S}_{2}$ in the system.
\end{abstract}

Keywords: platiniferous tetra-auricupride; Pt-for-Au substitution; platinum; gold; ophiolite; Bolshoy Khailyk placer; western Sayans; Russia

\section{Introduction}

\subsection{Sample Location and Objective}

Tetra-auricupride, $\mathrm{AuCu}$, an intermetallic mineral with a tetragonal symmetry, was first discovered in platiniferous ultrabasic rocks in the Sardala area, Xinjiang Autonomous Region, China [1]. It has since been reported from various localities worldwide (see below). In the majority of cases, the tetra-auricupride is platinum-free, and corresponds closely to the formula $\mathrm{AuCu}$. However, several of them contain elevated levels of $\mathrm{Pt}$; this is the case of the grain described here, originating in the Bol shoy Khailyk placer [2,3], western Sayans, Russia (Figure 1a,b). 
The coexistence of $\mathrm{Au}$ and $\mathrm{Pt}$ is highly uncommon, and has not been observed in other species. Our main objective here was to characterize our specimen of platiniferous tetra-auricupride from Bolshoy Khailyk both compositionally and, for the first time, structurally.

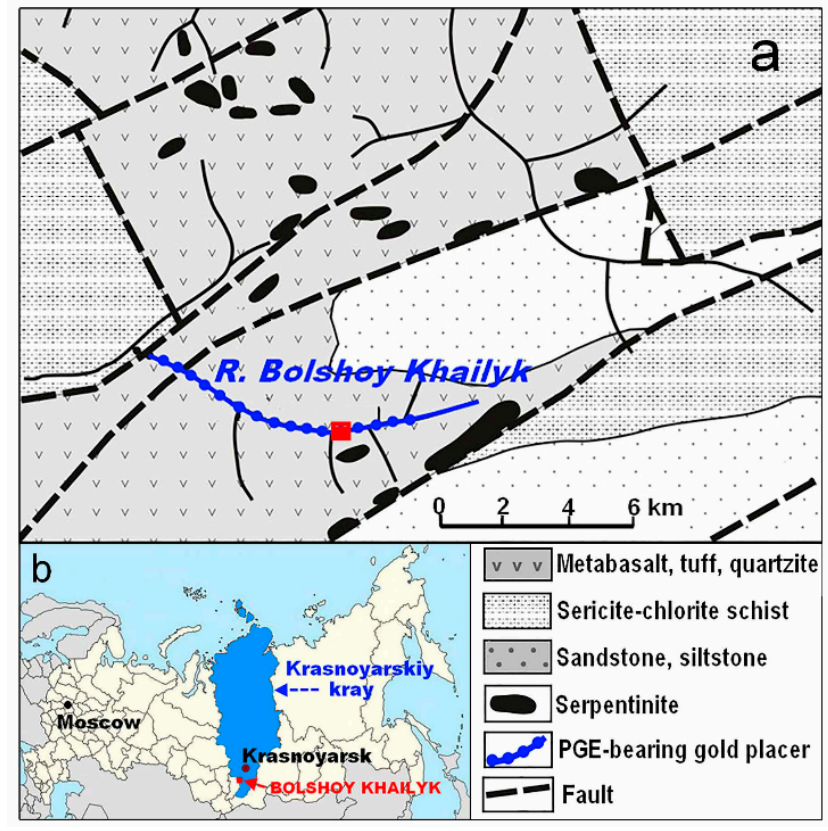

Figure 1. (a) Regional geology of the placer area at Bolshoy Khailyk (Figure 1a: simplified after [4]) and (b) a general map showing the location of the area in the Russian Federation (shown by red square symbol).

\subsection{Worldwide Occurrences of Tetra-Auricupride}

Tetra-auricupride has been documented in association with concentrically zoned Alaskan-Uralian(Aldan)-type complexes at Tulameen*, BC, Canada; Nizhniy Tagil, Urals; and Kondyor*, Aldan Shield, Russia [5-7]. It also occurs in layered mafic-ultramafic complexes at Jijal, Pakistan [8]; Yoko-Dovyrenskiy, southern Siberia [9]; Burakovskiy, Karelia, Russia [10]; and Skaergaard, Greenland [11,12]; and in serpentinized ophiolitic rocks on the island of Skyros [13] and the Pindos complex, Greece [14]. It was also found in ore at the Kerr-Addison mine, ON, Canada [15]; in the Itabira district, Minas Gerais, Brazil [16]; the Bleida Far West mine, Morocco [17]; the Sieroszowice mine, Poland [18]; and in association with Cu-Ni sulfide deposits of the Noril'sk complex, Krasnoyarskiy kray, Russia [19,20] and in the alkaline Coldwell gabbro-syenite complex in Ontario, Canada [21]. In addition, tetra-auricupride occurs in various alluvial deposits in the Sotajoki* area, Finland [22]; Durance, France [23,24]; in placers of the rivers Zolotaya* and Bolshoy Khailyk*, western Sayans [2,3,25]; Olkhovaya-1, Kamchatka krai, Russia [26]; and placers of the southeastern Samar island, Philippines [27]. The tetra-auricupride is notably platiniferous in suites indicated by an asterisk.

\section{Materials and Methods}

Our materials involved data published in the literature sources and the original results of the present investigation obtained on a detrital grain of tetra-auricupride from the western Sayans. This grain hosts a great variety of minute inclusions, some of which were presently studied using single-crystal electron backscatter diffraction (EBSD). We also employed synchrotron micro-Laue diffraction, wavelength-dispersive analysis (WDS), and scanning-electron microscopy (SEM) combined with energy-dispersive analysis (EDS). 


\subsection{Occurrence and Associated Minerals at Bolshoy Khailyk}

As noted, platiniferous tetra-auricupride was found as a detrital and composite grain associated with platinum-group minerals (PGMs) in a placer deposit at the River Bolshoy Khailyk, western Sayans, southern Krasnoyarskiy kray, Russia [2,3]. The river drains the Aktovrakskiy ophiolitic complex of dunite, harzburgite, and serpentinite, part of the Kurtushibinskiy belt (Figure 1).

An impressive enrichment in $\mathrm{Ru}$ is observed in the associated Os-Ir-Ru alloy minerals [3]. The minerals osmium, iridium, and ruthenium are the main PGMs in the Bolshoy Khailyk deposit. Isoferroplatinum-type alloys of $\mathrm{Pt}-\mathrm{Fe}$ are subordinate. Alloys of the series $(\mathrm{Pt}, \mathrm{Ir})(\mathrm{Ni}, \mathrm{Fe}, \mathrm{Cu})_{3-x}-(\mathrm{Ir}, \mathrm{Pt})$ $(\mathrm{Ni}, \mathrm{Fe}, \mathrm{Cu})_{3-x}$ are rare. The sulfide species observed in the placer represent members of the lauriteerlichmanite series, cooperite, bowieite (Cu-rich), a monosulfide-type phase $\left(\mathrm{Fe}_{0.40} \mathrm{Ni}_{0.39} \mathrm{Cu}_{0.19}\right)_{\Sigma 0.98} \mathrm{~S}_{1.02}$, a bornite-like phase $\left(\mathrm{Cu}_{4.06} \mathrm{Fe}_{1.47}\right)_{\Sigma 5.5} \mathrm{~S}_{4.5}$, a godlevskite-like phase $\mathrm{Ni}_{9.5} \mathrm{~S}_{7.5}$, and a thiospinel-like phase $\mathrm{Ni}[\mathrm{Ir}(\mathrm{Co}, \mathrm{Cu}, \mathrm{Fe})]_{2} \mathrm{~S}_{4}$. Less-common and rare minerals include sperrylite, a zoned oxide $\mathrm{Ru}_{6} \mathrm{Fe}^{3+}{ }_{2} \mathrm{O}_{15}$, and an uncommon variety of seleniferous and rhodiferous sperrylite $(\mathrm{Pt}, \mathrm{Rh})(\mathrm{As}, \mathrm{Se}, \mathrm{S})_{2}$.

Inclusions of clinopyroxene (diopside: $\mathrm{Wo}_{48.3-48.6} \mathrm{En}_{48.4-48.5} \mathrm{Fs}_{2.6} \mathrm{Ae}_{0.4-0.7} ; \mathrm{Mg} \#$ 96.9-97.9), chromian spinel (magnesiochromite: $\mathrm{Mg \#}$ up to 71), and serpentine are all rich in $\mathrm{Mg}$, consistent with the ultramafic source-rocks. Actinolite, magnesio-hornblende, and barroisite also are present in inclusions.

The placer grain (Figure 2) hosts numerous inclusions: magnetite poor in $\mathrm{Cr}, \mathrm{Mg}$, ( $\mathrm{Rh}, \mathrm{Co}$ )-rich pentlandite, members of the tulameenite-ferronickelplatinum series, a tolovkite-irarsite-hollingworthite solid solution, and a $\mathrm{Pt}(\mathrm{Cu}, \mathrm{Sn})$ phase [3]. In the present study, we reveal the presence of micrometric inclusions of geversite using electron backscatter diffraction (EBSD).

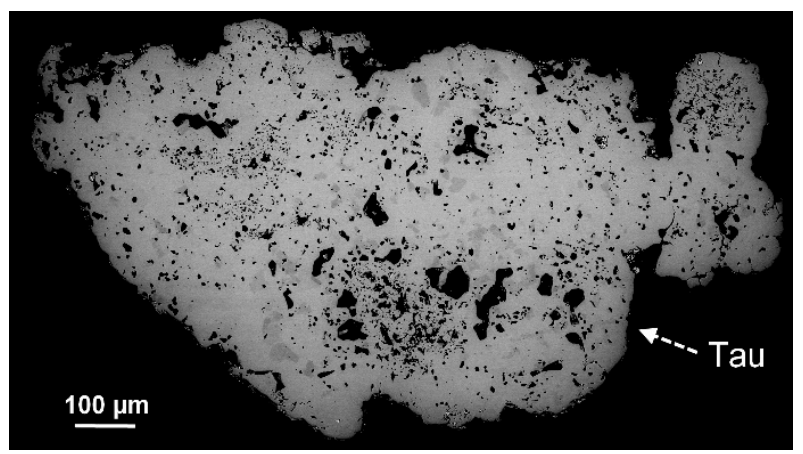

Figure 2. Back-scattered electron image showing the placer grain of platiniferous tetra-auricupride (Tau) from Bolshoy Khailyk. Black inclusions are filled with magnetite; gray phases are Rh-Co-bearing pentlandite and members of the tulameenite-ferronickelplatinum series.

\subsection{WDS and SEM/EDS Analyses}

Wavelength-dispersive analysis was done using a Camebax-micro electron microprobe at the Sobolev Institute of Geology and Mineralogy, Russian Academy of Sciences, Novosibirsk, Russia. The analytical conditions were $20 \mathrm{kV}$ and $60 \mathrm{nA}$; the $L \alpha$ line was used for $\mathrm{Ir}, \mathrm{Rh}, \mathrm{Ru}, \mathrm{Pt}$, and $\mathrm{Pd}$; the $M \alpha$ line was used for Os and $\mathrm{Au}$; and the $\mathrm{K} \alpha$ line was used for $\mathrm{Fe}, \mathrm{Ni}, \mathrm{Cu}$, and $\mathrm{Co}$. As standards, we used pure metals (for the platinum-group elements (PGEs) and $\mathrm{Au}$ ), $\mathrm{CuFeS}_{2}$, synthetic FeNiCo, and pure metals (for $\mathrm{Fe}, \mathrm{Cu}, \mathrm{Ni}$, and $\mathrm{Co}$ ). The minimum detection limit was $\leq 0.1 \mathrm{wt}$. \% for results of the WDS analyses. The SEM/EDS analyses were carried out at $20 \mathrm{kV}$ and $1.2 \mathrm{nA}$, using a Tescan Vega $3 \mathrm{SBH}$ facility combined with an Oxford X-Act spectrometer at the Siberian Federal University, Krasnoyarsk, Russia. Pure elements (for PGEs, Fe, and $\mathrm{Cu}$ ) were used as standards. The $L \alpha$ line was used for most of the PGEs except for Pt and $\mathrm{Au}(M \alpha$ line); the $\mathrm{K} \alpha$ line was used for $\mathrm{Fe}, \mathrm{Cu}$, and Ni.

\subsection{Synchrotron Micro-Laue Diffraction Study}

We have performed synchrotron X-ray scans of the grain of platiniferous tetra-auricupride from the western Sayans (Figure 2) on the basis of Laue microdiffraction measurements at beam line 12.3.2 
of the Advanced Light Source (ALS). The Laue diffraction patterns were collected using a PILATUS 1M area detector in reflection geometry. The observed patterns were indexed and analyzed using XMAS (version 6) [28]. A monochromator energy scan was performed to determine the lattice parameters.

\subsection{Single-Crystal Electron Backscatter Diffraction (EBSD)}

Single-crystal electron backscatter diffraction (EBSD) analyses of micrometer-sized inclusions were performed using an HKL EBSD system on a ZEISS 1550VP Field-Emission SEM (Carl Zeiss Inc., Oberkochenc, Germany), operated at $20 \mathrm{kV}$ and $6 \mathrm{nA}$ in focused-beam mode with a $70^{\circ}$ tilted stage and in a variable pressure mode $(25 \mathrm{~Pa})$. The focused electron beam is several nanometers in diameter. The spatial resolution for diffracted backscatter electrons is $\sim 30 \mathrm{~nm}$ in size. The EBSD system was calibrated using a single-crystal silicon standard.

\section{Results}

\subsection{Compositional Variations in Platiniferous Tetra-Auricupride}

The formula of the Pt-bearing tetra-auricupride from Bolshoy Khailyk and four other occurrences (Table 1) can be written $(\mathrm{Au}, \mathrm{Pt}) \mathrm{Cu}$.

Table 1. Compositions of platiniferous tetra-auricupride from Bolshoy Khailyk and other localities.

\begin{tabular}{|c|c|c|c|c|c|c|c|c|c|}
\hline$\#$ & 1 & 2 & 3 & 4 & 5 & 6 & 7 & 8 & 9 \\
\hline Locality & KHL & KHL & KHL & KHL & TUL & SOT & ZOL & KON & KON \\
\hline $\mathrm{Au}$ & $55.49-62.27$ & 59.69 & $58.46-63.22$ & 60.81 & 58.45 & 50.30 & 54.52 & $62.54-72.54$ & 66.15 \\
\hline $\mathrm{Pt}$ & $13.03-21.24$ & 15.23 & 13.79-18.14 & 15.67 & 15.80 & 20.40 & 14.69 & $3.12-11.79$ & 8.41 \\
\hline $\mathrm{Pd}$ & Bdl & bdl & bdl & bdl & bdl & 5.49 & 1.64 & bdl & bdl \\
\hline $\mathrm{Rh}$ & bdl & bdl & bdl & bdl & bdl & bdl & 0.51 & bdl & bdl \\
\hline Ir & bdl & bdl & bdl & bdl & bdl & bdl & 1.96 & bdl & bdl \\
\hline $\mathrm{Cu}$ & $23.68-26.07$ & 25.43 & $24.10-25.25$ & 24.52 & 23.51 & 22.00 & 22.68 & $23.52-24.69$ & 24.15 \\
\hline $\mathrm{Fe}$ & bdl-0.72 & bdl & bdl & bdl & bdl & 0.66 & bdl & bdl & bdl \\
\hline $\mathrm{Ni}$ & Bdl & bdl & bdl & bdl & bdl & 0.60 & bdl & bdl & bdl \\
\hline \multicolumn{10}{|c|}{ Atoms per formula unit (per a total of $2 \mathrm{apfu}$ ) } \\
\hline $\mathrm{Au}$ & $0.73-0.80$ & 0.77 & $0.77-0.83$ & 0.80 & 0.79 & 0.66 & 0.75 & $0.84-0.96$ & 0.88 \\
\hline $\mathrm{Pt}$ & $0.17-0.28$ & 0.20 & $0.18-0.24$ & 0.21 & 0.22 & 0.27 & 0.20 & $0.04-0.16$ & 0.11 \\
\hline $\mathrm{Au}+\mathrm{Pt}$ & $0.96-1.01$ & 0.98 & $0.99-1.02$ & 1.00 & 1.01 & 0.92 & 0.95 & $0.98-1.02$ & 1.00 \\
\hline $\mathrm{Pd}$ & 0 & 0 & 0 & 0 & 0 & 0.13 & 0.04 & 0 & 0 \\
\hline $\mathrm{Rh}$ & 0 & 0 & 0 & 0 & 0 & 0 & 0.01 & 0 & 0 \\
\hline Ir & 0 & 0 & 0 & 0 & 0 & 0 & 0.03 & 0 & 0 \\
\hline $\mathrm{Cu}$ & $0.96-1.04$ & 1.02 & 0.98-1.01 & 1.00 & 0.99 & 0.89 & 0.97 & $0.98-1.02$ & 1.00 \\
\hline $\mathrm{Fe}$ & $0-0.03$ & 0 & 0 & 0 & 0 & 0.03 & 0 & 0 & 0 \\
\hline $\mathrm{Ni}$ & 0 & 0 & 0 & 0 & 0 & 0.03 & 0 & 0 & 0 \\
\hline
\end{tabular}

Note: These results of EMP analyses expressed in wt. \% were obtained using WDS, except for columns 1 and 2, which represent quantitative SEM/EDS data. KHL is Bolshoy Khailyk, western Sayans, Russia (This study); TUL is the Tulameen Alaskan-type complex, BC, Canada [5]; SOT is the Sotajoki area in Finland [22]; ZOL is the Zolotaya River placer, western Sayans, Russia [25]; KON is the Kondyor concentrically zoned complex, northern Khabarovskiy kray, Russia [7]. "bdl" means "not detected" or "not analyzed". Columns 1, 3, and 8 display the observed ranges, and nos. 2, 4, and 9 pertain to mean results of point analyses, which are based on a total of 22, 10, and 5 individual analyses, respectively.

The proportion of $\mathrm{Pt}$ and $\mathrm{Au}$ defines a linear correlation. Up to $\sim 0.3 \mathrm{Pt}$ atoms per formula unit (apfu) can substitute for Au in this series (Figure 3a,b). The contents of Fe and Ni are minor; comparatively large quantities of $\mathrm{Pd}$ (up to $5.5 \mathrm{wt}$. \%) may also be present in solid solution in some of these examples [22]. 

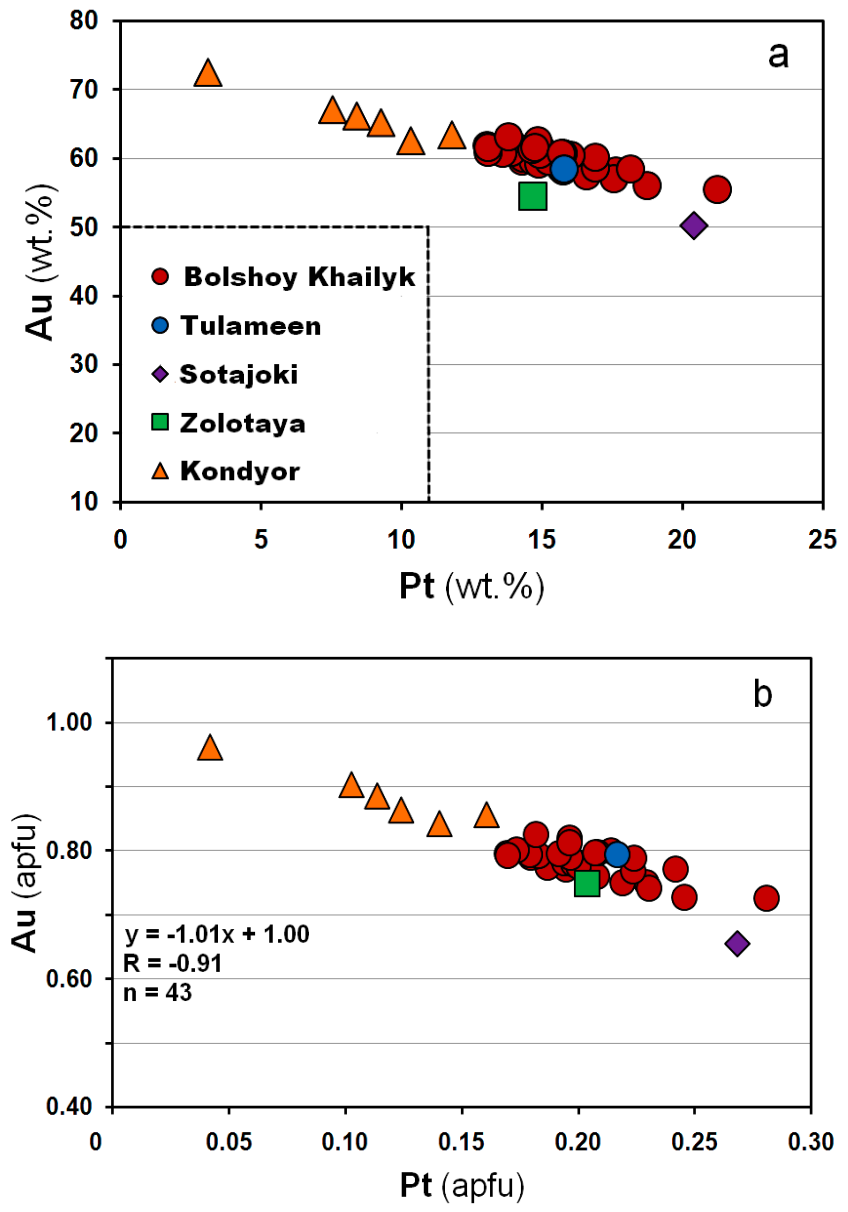

Figure 3. Plots of Pt vs. Au expressed in weight \% (a) and values of atoms per formula unit (apfu), on the basis of a total of 2 apfu (b), showing compositional variations in grains of tetra-auricupride from Bolshoy Khailyk (this study) and various localities reported in the literature.

\subsection{Synchrotron Micro-Laue Diffraction Study}

The Laue microdiffraction patterns of the studied specimen of platiniferous tetra-auricupride from the western Sayans are shown in Figure 4a,b and Figure 5, and listed in Table 2. The inferred unit-cell parameters of this phase are: $a 2.790(1) \AA, c 3.641(4) \AA$, with $c / a=1.305$; its space group is P4/mmm.

Table 2. X-ray diffraction pattern of platiniferous tetra-auricupride from Bolshoy Khailyk.

\begin{tabular}{ccccc}
\hline $\mathbf{h}$ & $\mathbf{k}$ & $\mathbf{1}$ & $\mathbf{d}$ (obs.) & $\mathbf{I}($ rel.) \\
\hline 0 & 0 & 1 & 3.63819 & 9.5 \\
1 & 0 & 0 & 2.79045 & 16.1 \\
1 & 0 & 1 & 2.21541 & 100 \\
1 & 1 & 0 & 1.97535 & 34.1 \\
1 & 1 & 1 & 1.73554 & 28.8 \\
1 & 0 & 2 & 1.52408 & 20.1 \\
2 & 0 & 0 & 1.39583 & 16.1 \\
1 & 1 & 2 & 1.33812 & 56.9 \\
2 & 0 & 1 & 1.30304 & 32.1 \\
2 & 1 & 0 & 1.24814 & 12.5 \\
2 & 1 & 1 & 1.1808 & 46.5 \\
\hline
\end{tabular}

Note: The powder-diffraction data were obtained by scans over a large area of the platiniferous tetra-auricupride phase (Figures 2 and 4a,b), d(obs.)—observed values; I(rel.)—intensity (I) is given in relative (rel.) units. 


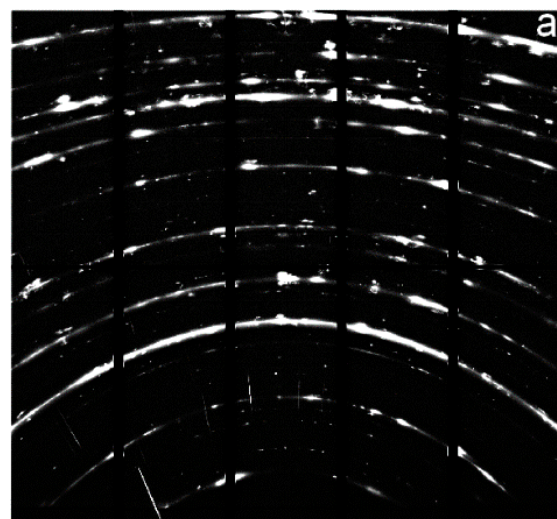

(a)

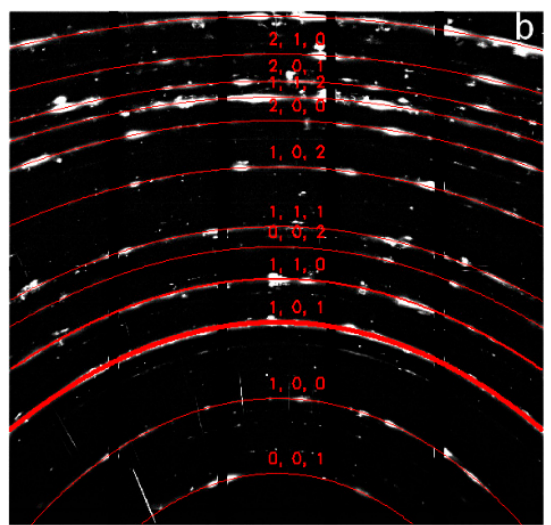

(b)

Figure 4. The observed and indexed powder-diffraction patterns (a and $\mathbf{b}$, respectively) of a specimen of platiniferous tetra-auricupride at Bolshoy Khailyk, which were obtained by summing scans over a large area of the matrix phase in the detrital grain shown in Figure 2.

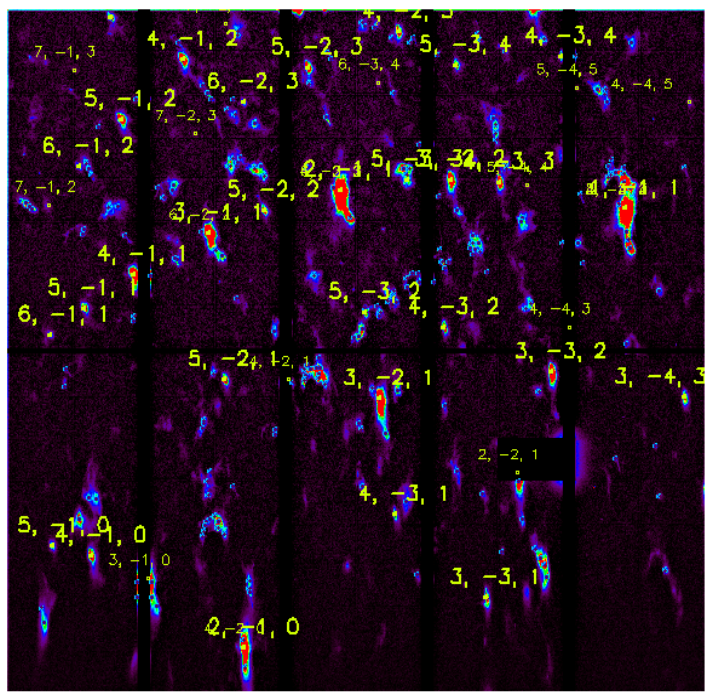

Figure 5. Indexed micro-Laue pattern of platiniferous tetra-auricupride from the western Sayans.

Our results are consistent with those obtained for the ordered $\mathrm{AuCu}(\mathrm{I})$ phase known in the $\mathrm{Au}-\mathrm{Cu}$ system, which has the following parameters: $a$ 2.785-2.810 $\AA$, $c$ 3.671-3.712 $\AA$, space group $P 4 / m m m$ [29]. Furthermore, they agree with the suggested revision [30]. Tetra-auricupride is quoted with $a 2.800 \AA, c 3.670 \AA$, space group $P 4 / \mathrm{mmm}$, that is close to the parameters of tetraferroplatinum, PtFe: $a 2.724 \AA, c 3.720 \AA$, which were also revised by this author. We can conclude that the incorporation of up to $30 \mathrm{~mol}$. \% of a "PtCu" component does not notably change the unit cell of tetra-auricupride. Note that hongshiite, $\mathrm{PtCu}$, is not an end member in this series. Hongshiite is trigonal, space group: R32, $R 3 m$, or $R \overline{3} m$, with the unit-cell parameters: $a 10.713 \AA, c 13.192 \AA, Z=48$ [31,32]; synthetic PtCu also adopts the trigonal structure [33].

Note that the holotype tetra-auricupride, of composition $\mathrm{Au}_{1.01} \mathrm{Cu}_{0.99}$, is different. Chen et al. (1982) [1] reported it to have the cell parameters $a 3.98 \AA, c 3.72 \AA, Z=2$, with $C 4 / m m m$ as the probable space group. These values agree with those reported for the $\mathrm{AuCu}(\mathrm{II})$ phase documented in the system Au-Cu: $a 3.96 \AA$, $b 3.97 \AA, c 3.68 \AA$, space group Imma [29].

The results of the EBSD analysis (Figure $6 a, b$ ) indicatethat micrometric inclusions in the tetra-auricupride matrix consistof geversite, $\mathrm{PtSb}_{2}$. 


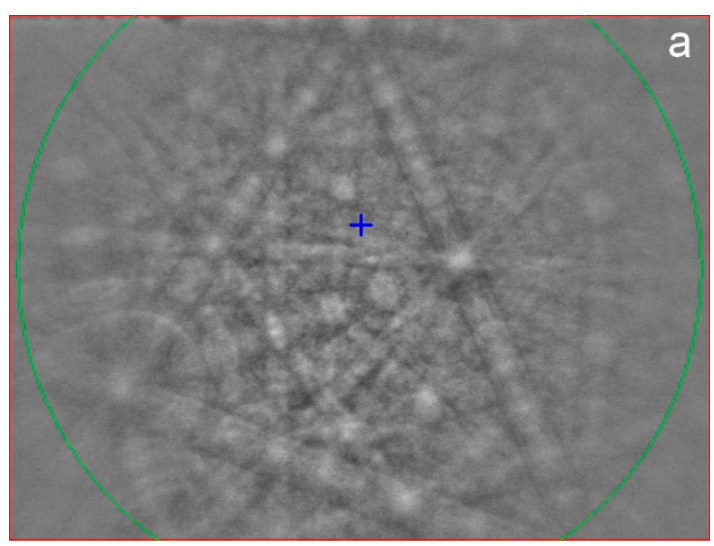

(a)

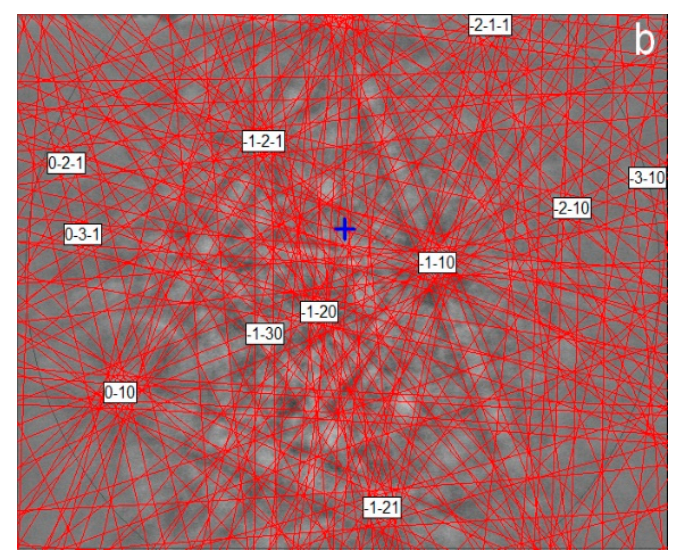

(b)

Figure 6. The observed and indexed EBSD patterns ( $\mathbf{a}$ and $\mathbf{b}$, respectively) obtained for micrometer-sized inclusion of geversite hosted by the placer grain of platiniferous tetra-auricupride at Bolshoy Khailyk.

\section{Discussion and Concluding Comments}

The strong dominance of Os-Ir-Ru alloy minerals, their patterns of Ru enrichment, and the regional association of detrital grains of PGMs and Pt-rich tetra-auricupride with exposed bodies of the Aktovrakskiy complex (Figure 1a) provide clear indications of an ophiolite origin of the PGE $+\mathrm{Au}$ mineralization at Bolshoy Khailyk. The platiniferous tetra-auricupride in the Zolotaya River placers is also spatially associated with serpentinites of this complex [25]. The high extent of $\mathrm{Cu}+\mathrm{Au}$ enrichment expressed by the presence of tetra-auricupride is considered to be a reflection of geochemical evolution and the buildup in levels of the incompatible $\mathrm{Cu}$ and $\mathrm{Au}$ with subordinate $\mathrm{Pt}$ in a remaining volume of melt during the bulk crystallization of Os-Ir-Ru alloy phases, after the early crystallization of chromian spinel and olivine [3]. Low levels of $\mathrm{O}_{2}$ and $\mathrm{S}_{2}$ fugacities are inferred to have existed in the system.

The suggested crystallization of the Pt-rich tetra-auricupride from a fractionated melt at a moderately low temperature is consistent with compositions of magnetite inclusions, which are poor in $\mathrm{Mg}$ and $\mathrm{Cr}$, in contrast to magnesiochromite inclusions in the associated grains of Os-Ir-Ru-rich PGM at Bolshoy Khailyk. It is known that tetra-auricupride (Pt-free) is a late phase deposited during serpentinization of ophiolitic rocks of Skyros Island, Greece [13]. Hydrothermal processes related to serpentinization are recognized to concentrate efficiently elevated levels of gold (1-10 ppm) in sulfide-rich varieties of serpentinites, or in carbonatized (listwaenite) varieties, or in silicified serpentinites associated with ophiolites [34,35].

We establish that in such a low-temperature environment, tetra-auricupride can incorporate as much as $~ 30 \mathrm{~mol}$. \% of a "PtCu" component, apparently without significant modification of the unit cell. This surprising level of incorporation of $\mathrm{Pt}$ for $\mathrm{Au}$ has not been documented in any other mineral. The unit-cell parameters of such platiniferous auricupride are close to those reported for ordered $\mathrm{AuCu}(\mathrm{I})$ in the $\mathrm{Au}-\mathrm{Cu}$ system, and are also close to the cell parameters of tetraferroplatinum (PtFe). In addition, both seem to crystallize in the same space group, $P 4 / \mathrm{mmm}$ [30]. These intermetallic compounds and natural alloys are thus isostructural. The closeness of the two structures presumably allows platinum to displace gold atoms so readily, possibly at conditions of disequilibrium growth.

As noted, the tetra-auricupride grain enriched in $\mathrm{Pt}$ at Bolshoy Khailyk hosts a variety of inclusions: $\mathrm{Cr}-\mathrm{Mg}-\mathrm{Mn}$-bearing magnetite, $\mathrm{Co}-(\mathrm{Rh})$-rich pentlandite and various platinum-group minerals: the tulameenite-ferronickelplatinum series ( $\left.\mathrm{Pt}_{2} \mathrm{FeCu}-\mathrm{Pt}_{2} \mathrm{FeNi}\right)$, a tolovkite (IrSbS)-irarsite (IrAsS)-hollingworthite (RhAsS) solid solution, geversite $\mathrm{PtSb}_{2}$ (this study), and unnamed $(\mathrm{Pt}, \mathrm{Pd})(\mathrm{Cu}, \mathrm{Sn})$, among others. On the basis of our experience, we note that EBSD analysis can be a useful tool to recognize micrometric inclusions of PGMs or other phases.

The ore-forming system thus involved at least 17 elements: $\mathrm{Cu}, \mathrm{Au}, \mathrm{Pt}, \mathrm{Rh}, \mathrm{Pd}, \mathrm{Ir}, \mathrm{Fe}, \mathrm{Co}, \mathrm{Ni}, \mathrm{S}$, $\mathrm{Sb}, \mathrm{As}, \mathrm{Sn}, \mathrm{Cr}, \mathrm{Mn}, \mathrm{Mg}$, and $\mathrm{O}$, present as major or minor constituents in the mineral assemblage in 
association with platiniferous tetra-auricupride. The observed diversity - the presence of compositions rich in $\mathrm{Cu}, \mathrm{Au}$, and $\mathrm{Sn}$, along with PGE species having lower melting points (Rh and Pd) and metalloids ( $\mathrm{Sb}$ and $\mathrm{As}$ ) - is consistent with crystallization from a highly fractionated melt remaining after the deposition of primary phases such as highly magnesian olivine, magnesiochromite, and alloys of Os-Ir-Ru and (Pt,Ir) $)_{3}$ Fe. The upper limit of stability of a synthetic variant of ordered AuCu(II) is $410{ }^{\circ} \mathrm{C}$, whereas the temperature of the phase transition of $\mathrm{AuCu}$ (II) to $\mathrm{AuCu}$ (I) varies under different conditions of synthesis and is generally close to $385^{\circ} \mathrm{C}[29,36]$. The observed incorporation of high amounts of $\mathrm{Pt}$ is expected to somewhat increase the crystallization temperature of the platiniferous $\mathrm{AuCu}(\mathrm{I})$ phase at Bolshoy Khailyk. Nevertheless, this phase presumably crystallized at a relatively low temperature, which is unlikely to have exceeded $\sim 600-800^{\circ} \mathrm{C}$. This temperature is consistent with deposition from a droplet of residual melt.

Author Contributions: Authors wrote the article together. A.Y.B., R.F.M. and B.W. provided the interpretation of data and conclusions of the research, including results of synthesis of $\mathrm{AuCu}(\mathrm{I})$-type compounds (B.W.). N.T., C.V.S. and C.M. contributed results of the micro-Laue and EBSD studies. G.I.S. collected placer samples and completed a field work on the Bolshoy Khailyk placer deposit.

Funding: A.Y.B. gratefully acknowledges a partial support of this investigation by the Russian Foundation for Basic Research (project \# RFBR 19-05-00181).

Acknowledgments: We thank two reviewers and the Editorial board for their comments and suggestions. This research used beamline 12.3.2 at the Advanced Light Source, which is a DOE Office of Science User Facility under contract no. DE-AC02-05CH11231.

Conflicts of Interest: There is no conflict of interests.

\section{References}

1. Chen, K.; Yu, T.; Zhang, Y.; Peng, Z. Tetra-auricupride, CuAu discovered in China. Sci. Geol. Sin. 1982, 17, 111-116, (In Chinese with English abstract).

2. Shvedov, G.I.; Nekos, V.V. PGM of a placer at the R. Bolshoy Khailyk (western Sayans). Geol. Resour. Krasnoyarskiy Kray 2008, 9, 240-248. (In Russian)

3. Barkov, A.Y.; Shvedov, G.; Silyanov, S.; Martin, R.F. Mineralogy of platinum-group elements and gold in the ophiolite-related placer of the River Bolshoy Khailyk, western Sayans, Russia. Minerals 2018, 8, 247. [CrossRef]

4. Aleksandrov, G.P.; Gulyaev, Y.S. The Geological Map of the USSR (scale 1:200 000; M-46-III); The Western Sayan Series; Nedra Press: Moscow, Russia, 1966.

5. Cabri, L.J.; Laflamme, J.H.G. Analyses of minerals containing platinum-group elements. In Platinum-group elements: Mineralogy, Geology, Recovery (L.J. Cabri, ed.). Can. Inst. Min. Metall. 1981, 23, 151-173.

6. Yushkin, N.P. (Ed.) Mineralogy of the Urals: Native Elements, Carbides, Sulfides; The Uralian branch of the USSR Academy of Sciences: Sverdlovsk, Russia, 1990; pp. 92-97. (In Russian)

7. Nekrasov, I.Y.; Lennikov, A.M.; Zalishchak, B.L.; Oktyabrsky, R.A.; Ivanov, V.V.; Sapin, V.I.; Taskaev, V.I. Compositional variations in platinum-group minerals and gold, Konder alkaline-ultrabasic massif, Aldan Shield, Russia. Can. Miner. 2005, 43, 637-654. [CrossRef]

8. Miller, D.; Loucks, R.R. Platinum-group Element Mineralization in the Jijal layered ultramafic-mafic complex, Pakistani Himalayas. Econ. Geol. 1991, 86, 1093-1102. [CrossRef]

9. Rudashevskiy, N.S.; Krecer, D.A.; Orsoev, D.A.; Kislov, E.V. Palladium-platinum mineralization in vein $\mathrm{Cu}-\mathrm{Ni}$-ores of Yoko-Dovyrenskiy layered massif. Dokl. Akad. Nauk 2003, 391, 519-522. (In Russian)

10. Grokhovskaya, T.L.; Lapina, M.I.; Ganin, V.A.; Grinevich, N.G. PGE mineralization in the Burakovskiy Layered Complex, Southern Karelia, Russia. Geol. Rudn. Mestorozhd. 2005, 47, 315-341. (In Russian)

11. Holwell, D.A.; Keays, R.R.; McDonald, I.; Williams, M.R. Extreme enrichment of Se, Te, PGE and Au in $\mathrm{Cu}$ sulfide microdroplets: Evidence from LA-ICP-MS analysis of sulfides in the Skaergaard Intrusion, east Greenland. Contrib. Mineral. Petrol. 2015, 170, 1-26. [CrossRef] 
12. Nielsen, T.F.; Andersen, J.Ø.; Holness, M.B.; Keiding, J.K.; Rudashevsky, N.S.; Rudashevsky, V.N.; Veksler, I.V. The Skaergaard PGE and gold deposit: The result of in situ fractionation, sulphide saturation, and magma chamber-scale precious metal redistribution by immiscible Fe-rich melt. J. Petrol. 2015, 56, 1643-1676. [CrossRef]

13. Tarkian, M.; Economou-Eliopoulos, M.; Eliopoulos, D.G. Platinum-group minerals and tetra-auricupride in ophiolitic rocks of Skyros island, Greece. Miner. Petrol. 1992, 47, 55-66. [CrossRef]

14. Kapsiotis, A.; Grammatikopoulos, T.A.; Tsikouras, B.; Hatzipanagiotou, K. Platinum-Group mineral characterization in concentrates from high-grade PGE Al-rich chromitites of Korydallos area in the Pindos ophiolite complex (NW Greece). Resour. Geol. 2010, 60, 178-191. [CrossRef]

15. Knipe, S.W.; Fleet, M.E. Copper-gold alloy minerals from the Kerr mine, Ontario. Can. Miner. 1997, 35, 573-586.

16. Kwitko, R.; Cabral, A.R.; Lehmann, B.; Laflamme, J.G.; Cabri, L.J.; Criddle, A.J.; Galbiatti, H.F. Hongshiite, $\mathrm{PtCu}$, from itabirite-hosted Au-Pd-Pt mineralization (jacutinga), Itabira district, Minas Gerais, Brazil. Can. Miner. 2002, 40, 711-723. [CrossRef]

17. El Ghorfi, M.; Oberthür, T.; Melcher, F.; Lüders, V.; El Boukhari, A.; Maacha, L.; Ziadi, R.; Baoutoul, H. Gold-palladium mineralization at Bleïda Far West, Bou Azzer-El Graara Inlier, Anti-Atlas, Morocco. Miner. Depos. 2006, 41, 549-564. [CrossRef]

18. Pieczonka, J.; Piestrzyński, A.; Mucha, J.; Głuszek, A.; Kotarba, M.; Więcław, D. The red-bed-type precious metal deposit in the Sieroszowice-Polkowice copper mining district, SW Poland. Ann. Soc. Geologorum Pol. 2008, 78, 151-280.

19. Spiridonov, E.M.; Kulagov, E.A.; Serova, A.A.; Kulikova, I.M.; Korotaeva, N.N.; Sereda, E.V.; Tushentsova, I.N.; Belyakov, S.N.; Zhukov, N.N. Genetic Pd, Pt, Au, Ag, and Rh mineralogy in Noril'sk sulfide ores. Geol. Ore Depos. 2015, 57, 402-432. [CrossRef]

20. Vymazalová, A.; Laufek, F.; Sluzhenikin, S.F.; Stanley, C.J. Norilskite, $(\mathrm{Pd}, \mathrm{Ag})_{7} \mathrm{~Pb}_{4}$, a new mineral from Noril'sk -Talnakh deposit, Russia. Miner. Mag. 2017, 81, 531-541. [CrossRef]

21. McDonald, A.M.; Cabri, L.J.; Stanley, C.J.; Good, D.J.; Redpath, J.; Lane, G.; Spratt, J.; Ames, D.E. Coldwellite, $\mathrm{Pd}_{3} \mathrm{Ag}_{2} \mathrm{~S}$, a new mineral species from the Marathon deposit, Coldwell complex, Ontario, Canada. Can. Miner. 2015, 53, 1-13. [CrossRef]

22. Törnroos, R.; Vuorelainen, Y. Platinum-group metals and their alloys in nuggets from alluvial deposits in Finnish Lapland. Lithos 1987, 20, 491-500.

23. Ohnenstetter, M.; Johan, Z.; Fisher, W.; Amosse, J. Platinum-Group Minerals from the Durance River Alluvia, France; Papunen, H., Ed.; Bulletin of the Geological Society of Finland: Espoo, Finland, 1989; Volume 61, p. 46.

24. Johan, Z.; Ohnenstetter, M.; Fischer, M.; Amossé, J. Platinum-group minerals from the Durance River alluvium, France. Miner. Petrol. 1990, 42, 287-306. [CrossRef]

25. Tolstykh, N.D.; Krivenko, A.P.; Pospelova, L.N. Unusual compounds of iridium, osmium and ruthenium with selenium, tellurium and arsenic from placers of the Zolotaya River (western Sayans). Zap. Vsesoyuzn. Miner. Obshch. 1997, 126, 23-34. (In Russian)

26. Sandimirova, E.I.; Sidorov, E.G.; Chubarov, V.M.; Ibragimova, E.K.; Antonov, A.V. Native metals and intermetallic compounds in heavy concentrate halos of the Ol'khovaya-1 River, Kamchatsky Mys Peninsula, eastern Kamchatka. Geol. Ore Depos. 2014, 56, 657-664. [CrossRef]

27. Oberthür, T.; Melcher, F.; Weiser, T.W. Detrital platinum-group minerals and gold in placers of southeastern Samar Island, Philippines. Can. Miner. 2017, 55, 45-62. [CrossRef]

28. Tamura, N. XMAS: A Versatile Tool for Analyzing Synchrotron X-ray Microdiffraction Data. In Strain and Dislocation Gradients from Diffraction; Barabash, R., Ice, G., Eds.; Imperial College Press: London, UK, 2014; pp. 125-155.

29. Okamoto, H.; Chakrabarti, D.J.; Laughlin, D.E.; Massalski, T.B. The Au-Cu (Gold-Copper) system. J. Phase Equilib. 1987, 8, 454-474. [CrossRef]

30. Bayliss, P. Revised unit-cell dimensions, space group, and chemical formula of some metallic minerals. Can. Miner. 1990, 28, 751-755.

31. Yu, Z. New data on hongshiite. Bull. Inst. Geol. 1982, 1982, 75-81, (In Chinese with English abstract). Am. Miner. 1984, 69, 411-412.

32. Yu, Z. New data for hongshiite. Acta Geol. Sin. 2001, 75, 400-403, (In Chinese with English Abstract). 
33. Wyckoff, R.W.G. The Second Edition of Structure of Crystals by Wyckoff Published by The Chemical Catalog Company; INC: New York, NY, USA, 1931; p. 225.

34. Buisson, G.; Leblanc, M. Gold in mantle peridotites from upper Proterozoic ophiolites in Arabia, Mali, and Morocco. Econ. Geol. 1987, 82, 2091-2097. [CrossRef]

35. Leblanc, M. Platinum-Group Elements and Gold in Ophiolitic Complexes: Distribution and Fractionation from Mantle to Oceanic Floor. Petrol. Struct. Geol. 1991, 231-260. [CrossRef]

36. Lamiri, I.; Martínez-Blanco, D.; Abdelbaky, M.S.M.; Mari, D.; Hamana, D.; García-Granda, S. Investigation of the order-disorder phase transition series in AuCu by in-situ temperature XRD and mechanical spectroscopy. J. Alloys Compd. 2019, 770, 748-754. [CrossRef]

(C) 2019 by the authors. Licensee MDPI, Basel, Switzerland. This article is an open access article distributed under the terms and conditions of the Creative Commons Attribution (CC BY) license (http://creativecommons.org/licenses/by/4.0/). 